\title{
Interpreting \\ the Labour Party
}

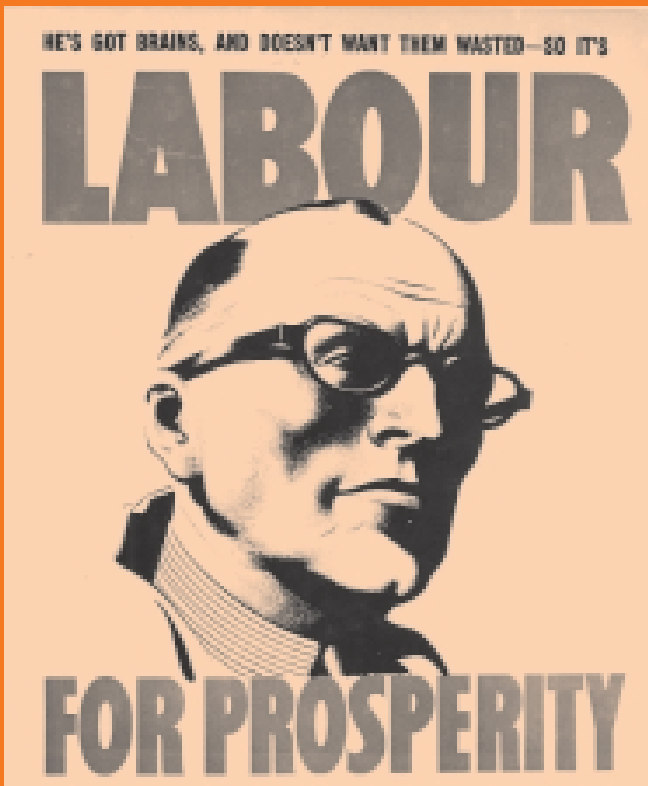

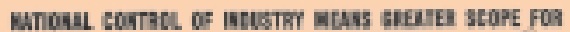

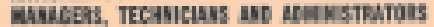

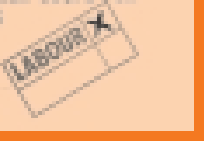

\section{Approaches to Labour politics and history}

Edited by John Callaghan, Steven Fielding and Steve Ludlam 


\section{Interpreting the Labour Party}

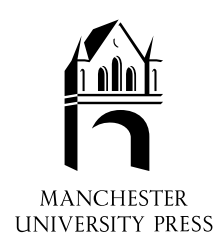




\section{Critical Labour Movement Studies Series}

Series editors

John Callaghan

Steven Fielding

Steve Ludlam 


\section{Interpreting \\ the Labour Party}

\section{Approaches to Labour politics and history}

edited by

John Callaghan

Steven Fielding

Steve Ludlam

Manchester University Press

Manchester and New York

distributed exclusively in the USA by Palgrave 
Copyright (C) Manchester University Press 2003

While copyright in the volume as a whole is vested in Manchester University Press, copyright in individual chapters belongs to their respective authors, and no chapter may be reproduced wholly or in part without the express permission in writing of both author and publisher.

Published by Manchester University Press

Oxford Road, Manchester M13 9NR, UK

and Room 400, 175 Fifth Avenue, New York, NY 10010, USA

www.manchesteruniversitypress.co.uk

Distributed exclusively in the USA by

Palgrave, 175 Fifth Avenue, New York,

NY 10010, USA

Distributed exclusively in Canada by

UBC Press, University of British Columbia, 2029 West Mall,

Vancouver, BC, Canada V6T 1Z2

British Library Cataloguing-in-Publication Data

A catalogue record for this book is available from the British Library

Library of Congress Cataloging-in-Publication Data applied for

ISBN 0719067189 hardback

0719067197 paperback

First published 2003

$\begin{array}{lllllllll}11 & 10 & 09 & 08 & 07 & 06 & 05 & 04 & 03\end{array}$

$\begin{array}{lllllllllll}10 & 9 & 8 & 7 & 6 & 5 & 4 & 3 & 2 & 1\end{array}$

Typeset

by Northern Phototypesetting Co. Ltd., Bolton, Lancs.

Printed in Great Britain

by CPI, Bath 